than I originally intended on the subject, which, as standing first on the muster roll of the Association, and as having been so recently and repeatedly arraigned before the bar of public opinion, is entitled to be heard in its defence (if anywhere) in this place,-having endeavoured to show what it is not, what it is, and what it is probably destined to become, I feel that I must enough and more than enough have trespassed on your forbearance.

J. J. SYLVESTER

The remarks on the use of experimental methods in mathematical investigation led to Dr. Jacobi, the eminent physicist of St. Petersburg, who was present at the delivery of the foregoing address, favouring me with the annexed anecdote relative to his illustrious brother, C. G. J. Jacobi* -

"En causant un jour avec mon frère défunt sur la nécessité de contrôler par des expériences réitérées toute observation, même si elle confirme l'hypothèse, il me raconta avoir découvert un jour une loi très-remarquable de la théorie des nombres, dont il ne douta guère qu'elle fút générale. Cependant par un excès de précaution ou plutôt pour faire le superflu, il voulut substituer un chiffre quelconque réel aux termes généraux, chiffre qu'il choisit au hasard, ou, peut-être, par une espèce de divination, car en effet ce chiffre mit sa formule en défaut; tout autre chiffre qu'il essaya en confirma la généralité. Plus tard il réussit à prouyer que le chiffre choisi par lui par hasard, appartenait à un système de chiffres qui faisait la seule exception à la règle.

"Ce fait curieux m'est resté dans la mémoire, mais comme il s'est passé il y a plus d'une trentaine d'années, je ne rappelle plus les détails.

"Exeter, 24 Août, r869."

\section{THE NEW TELESCOPE AT ETON}

$\mathrm{I} \mathrm{N}$ furtherance of natural science work at Eton, an excellent telescope has been recently given to the school by the energy and liberality of some of the masters.

The instrument is a refractor, with object glass of 5.9 inches clear aperture, and 88 inches focus, and was made by Messrs. Cooke and Sons, of York, who also supplied the observatory and superintended the erection of the telescope. It is, as will be seen from the engraving, mounted equatorially on the German system, with declination circle reading to $\mathrm{IO}^{\prime \prime}$ of arc, and hour circle reading to $2^{\prime \prime}$ of time. The mechanical details do not, with one exception, deviate materially from the pattern usually adopted by Messrs. Cooke, whose name is a guarantee for skill of design and excellence of workmanship. The exception alluded to is in the construction of the driving clock, the speed of which is not regulated, as usual, by a centrifugal governor, or fly, alone, but by a 'fly supplemented by an ordinary clock escapement. This arrangement is quite new, and is the invention of the late $\mathrm{Mr}$. 'T. Cooke, the senior partner in the firm. It was described by him in a paper read before the Royal Astronomical Society a short time ago. The details would hardly be intelligible without drawings, but the general mode of action is as follows :-

The barrel is connected with two trains of wheel-work : one (the lowest wheel of which gives motion in the ordinary

* $\mathrm{It}$ is said of Jacobi, that he attracted the particular attention and friend ship of Böckh, the director of the philological seminary at Berlin, by the zeal and talent he displayed for philology, and only at the end of two years study at the University, and after a severe mental struggle, was able to make his final choice in favour of mathematics. The relation between thes two sciences is not perhaps so remote as may at first sight appear; and indeed it has often struck me that metamorphosis runs like a golden threa through the most diverse branches of modern intellectual culture, and form a natural link of connection between subjects in their aims so remote a grammar, philology, ethnology, rational mythology, chemistry, botany, com parative anatomy, physiology, physics, algebra, rersification, music, all of which, under the modern point of view, may be regarded as having morphology for their common centre. Even singing, I have been told, the advanced German theorists regard as being strictly a development of recitative, and infer therefrom that no essentially new melodic themes can be invented until a social cataclysm, or the civilisation of some at present barbaric races, shall have created fresh necessities of expression, and called into activity new forms of impassioned declamation. way to the telescope) is terminated by a fly of insufficient power per se to reduce the speed within proper limits; the other train is terminated by a half-dead escapement of the usual kind. One of the wheels of the fly-train has a broad rim, on which presses a brake actuated by a wheel in the escapement train. When the escapement is stopped, this brake presses on the wheel with sufficient force to stop the motion of the clock entirely. When the escapement is set to work the brake is released, and the fly-train moves, communicating motion to the telescope. If the speed becomes too great, so as to outrun the escapement, the latter immediately applies increased brake-power, and checks the motion of

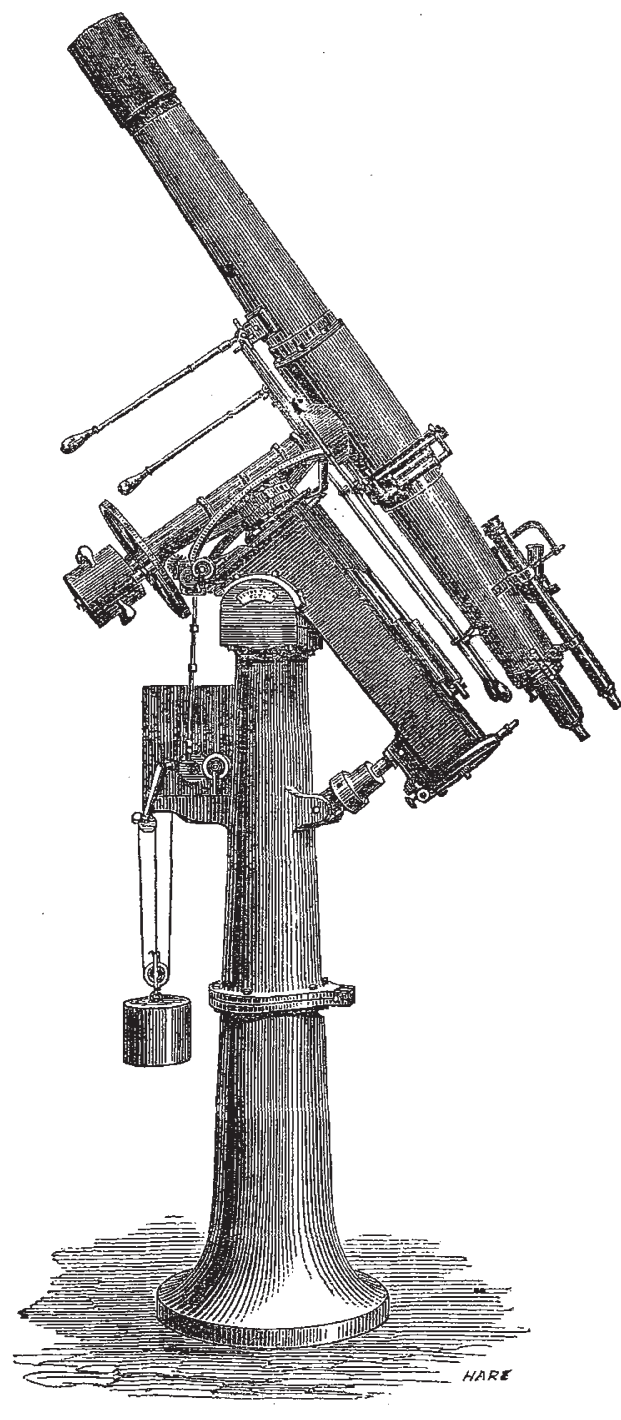

THE RTON EQUATORIAE

the fly; and vice vers $\hat{a}$, if from increased friction or other cause the motion is too slow, so that the fly lags behind the escapement, the brake-spring is relaxed by the latter until the due speed is regained. Thus the two trains are balanced against each other, and since one of the wheels of the escapement-train is, as in some forms of train remontoires, supported in a swinging-frame (which frame, in fact, controls the brake-spring), the intermittent motion of the escapement does not reach the telescope. This clock seems to work very smoothly; and not the least advantage of the arrangement is the facility with which 